\title{
Wpływ maksymalnej temperatury cyklu cieplnego na właściwości symulowanej SWC stali obrabianej termomechanicznie S700MC
}

\section{Influence of the maximum temperature of the thermal cycle on properties of the simulated HAZ thermomechanically treated steel S700MC}

\section{Streszczenie}

W pracy przedstawiono wyniki badań wpływu maksymalnej temperatury cyklu cieplnego na właściwości symulowanej SWC stali obrabianej termomechanicznie o wysokiej granicy plastyczności S700MC. Badania przeprowadzono na specjalnie zbudowanym stanowisku badawczym wyposażonym w rezystancyjne źródło nagrzewania, kamerę termowizyjną Variocam Head HR i stanowisko komputerowe. Badania symulacji cykli cieplnych polegały na nagrzewaniu rezystancyjnym próbek przygotowanych do badania udarności oraz rejestracji cyklu cieplnego nagrzewania i chłodzenia. Symulowano pojedyncze cykle cieplne w zakresie temperatury od 400 do $1300^{\circ} \mathrm{C}$, co $100^{\circ} \mathrm{C}$, oraz cykle złożone. W czasie badania rejestrowano przebieg temperatury $w$ funkcji czasu oraz wyznaczono następujące parametry:

- $T_{\text {max }}$ - maksymalną temperaturę cyklu,

- $t_{n}$ - czas nagrzewania próbki od temp. $50^{\circ} \mathrm{C}$ do $T_{\text {max }}$,

- $\mathrm{t}_{8}$ - czas, po jakim temp. obniżyła się do $800^{\circ} \mathrm{C}$,

- $t_{5}$ - czas, po jakim temp. obniżyła się do $500^{\circ} \mathrm{C}$,

- $\mathrm{t}_{8 / 5}$ - czas stygnięcia w zakresie temp. $800 \div 500^{\circ} \mathrm{C}$.

Uzyskane próbki po procesie symulacji zostały poddane badaniom udarności, pomiarowi twardości oraz badaniom metalograficznym mikroskopowym. W celu określenia właściwości wytrzymałościowych i plastycznych symulowanej strefy wpływu ciepła stali S700MC przeprowadzono próbę rozciągania materiału na próbkach okrągłych.

\section{Abstract}

In this paper an influence of simulated thermal cycle on properties and HAZ structure of thermomechanically treated steel S700MC. The simulation of thermal cycles was carried out on a specially built test stand equipped with resistive heating source infrared camera VarioCam Head HR with $50 \mathrm{~mm}$ lens and a computer with software IRBIS 3 plus. Simulation was prepared for simple and complex thermal cycle. Simulation studies of thermal cycles consisted of resistive heating of samples prepared for the impact test. Single thermal cycles were simulated at temperatures ranging from 400 to $1300^{\circ} \mathrm{C}, 100^{\circ} \mathrm{C}$ and the cycle complex. For each temperature three repeats were carried out. During the course of the study, the temperature was recorded as a function of time and the following parameters were established:

- $T_{\max }$ - specimen max. temperature,

- $t_{n}$ - specimen heating time from $50^{\circ} \mathrm{C}$ up to $T_{\text {max }}$,

- $t_{8}$ - time for temperature decreasing below $800^{\circ} \mathrm{C}$,

$-t_{5}$ - time for temperature decreasing below $500^{\circ} \mathrm{C}$,

- $t_{8 / 5}$-specimen cooling time (temperatures range $800 \div 500^{\circ} \mathrm{C}$ ).

The resulting sample, the simulation process, have been tested toughness, hardness measurement and metallurgical research microscope. In order to determine the strength and plastic properties of simulated heat-affected zone S700MC steel tensile test was carried out on samples of material round.

Dr inż. Jacek Górka - Politechnika Śląska, Gliwice. 


\section{Wstęp}

Spawalność materiałów konstrukcyjnych można wyznaczyć za pomoca metod teoretycznych, które maja na celu analizę przemian fazowych stali w procesie spawania, jak również przez analizę właściwości materiału w strefie wpływu ciepła (SWC). Analizę przemian fazowych stali przeprowadza się na podstawie wykresów CTPc-S rozpadu przechłodzonego austenitu w warunkach spawalniczych cykli cieplnych. Cykl cieplny spawania, czyli zmiany temperatury punktów złącza w czasie, obejmuje zmiany temperatury pod wpływem przepływu ciepła w każdym punkcie danej objętości oraz efekty działania tych zmian. Rodzaj cyklu cieplnego, jakiemu został poddany dany metal spoiny, jak i SWC, ma wpływ na właściwości strukturalne i mechaniczne. Sterowanie dynamiką przepływu ciepła jest warunkiem pomyślnego przeprowadzenia procesu spawania. Rodzaj przemian strukturalnych i wynikające $z$ nich właściwości strefy wpływu ciepła zależne są od temperatury maksymalnej cyklu cieplnego oraz od czasu stygnięcia $t_{8 / 5}$. Ze wzrostem temperatury maksymalnej zwiększa się stopień przegrzania austenitu, rozrost jego ziaren oraz ilość rozpuszczonych w austenicie wydzieleń, co opóźnia przemianę $\gamma \rightarrow \alpha$ podczas chłodzenia i przesuwa ją w kierunku niższej temperatury. Chcąc określić najbardziej niekorzystne właściwości SWC, należy brać pod uwage przede wszystkim cykle cieplne o najwyższej temperaturze maksymalnej. Warunki austenityzowania występujące w SWC różnią się od warunków stosowa-

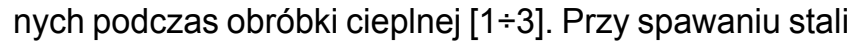
drobnoziarnistych wysokowytrzymałych należy zwrócić uwagę na:

- stosowanie właściwych materiałów dodatkowych do spawania, zawierających składniki stopowe zapewniające odpowiedni poziom właściwości wytrzymałościowych spoiny w stosunku do materiału rodzimego - ilość wprowadzonego ciepła do złącza - energię liniową, temperaturę międzyściegową [4]

- strukturę spoin (spoiny wielościegowe).

Mikrostruktura SWC wielościegowego złącza spawanego zależy od składu chemicznego stali, intensywności źródła ciepła oraz liczby układanych ściegów. Zarówno prędkość chłodzenia, jak i ilość wprowadzonego ciepła mają duży wpływ na strukturę strefy wpływu ciepła oraz strukturę spoiny. Podczas spawania stali obrabianej termomechanicznie do spoiny wprowadzane zostają mikrododatki niobu, wanadu i tytanu. Podczas chłodzenia wydzielają się one w postaci węglików i węglikoazotków. Ilość wydzieleń zależy od szybkości chłodzenia. Im jest szybsze, tym więcej mikrododatków zostaje zatrzymanych w roztworze. Podobna sytuacja występuje w strefie wpływu ciepła. llość mikrododatków, które zostały w roztworze, ma istotny wpływ na przemiany fazowe w czasie chłodzenia i zmiany właściwości po obróbce cieplnej $[5,6]$. Powoduje to wzrost udziału produktów przemiany bezdyfuzyjnej i pośredniej (bainitycznej). Struktury te $w$ dużej mierze są przyczyną obniżenia udarności, zwłaszcza w przypadku szerokiej strefy wpływu ciepła. Efekt ten jest potęgowany, gdy spawanie odbywa się z wysokimi energiami liniowymi i wydłuża się czas chłodzenia $\mathrm{t}_{815}$. Zarówno prędkość chłodzenia, jak i ilość wprowadzonego ciepła mają duży wpływ na strukturę strefy wpływu ciepła oraz strukturę spoiny. Przy dużych prędkościach chłodzenia typową strukturą SWC stali obrabianych termomechanicznie jest dolny bainit wykazujący zadowalającą odporność na pękanie kruche. Wprowadzenie dużych ilości ciepła do złącza spawanego wydłuża czas wytrzymania SWC w wysokiej temperaturze i zmniejsza szybkość chłodzenia. Prowadzi to do rozrostu ziarna austenitu i do pojawienia się, szczególnie w strefie przyległej do linii wtopienia, struktur o gorszych właściwościach plastycznych. W strukturze SWC dominuje wtedy bainit górny oraz ferryt pierwotny i bocznopłytkowy $[7,8]$.

\section{Badania własne}

Celem badań było określenie właściwości i struktury obszarów SWC stali S700MC o grubości $10 \mathrm{~mm}$, nagrzewanych do różnych maksymalnych temperatur cyklu cieplnego. Skład chemiczny oraz właściwości mechaniczne stali przedstawiono w tablicach I i II, a strukturę na rysunku 1.

Tablica I. Skład chemiczny wg PN EN 10149-2 i właściwości mechaniczne stali walcowanej termomechanicznie do kształtowania na zimno S700MC

Table I. The chemical composition according to the regulation PN EN 10149-2 and mechanical properties of the S700 MC steel subjected to thermomechanical treatment used for cold moulding

\begin{tabular}{|c|c|c|c|c|c|c|c|c|c|c|c|}
\hline \multicolumn{12}{|c|}{ Stężenie pierwiastków, \% } \\
\hline $\begin{array}{c}\mathrm{C} \\
\max \end{array}$ & $\begin{array}{c}\mathrm{Si} \\
\max \end{array}$ & $\begin{array}{l}\mathrm{Mn} \\
\max \end{array}$ & $\begin{array}{c}\mathrm{P} \\
\max \end{array}$ & $\begin{array}{c}S \\
\max \end{array}$ & $\begin{array}{l}\mathrm{Al}_{\text {cakk. }} \\
\text { min. }\end{array}$ & $\begin{array}{l}\mathrm{Nb}^{*} \\
\max .\end{array}$ & $\begin{array}{c}\mathrm{V} \\
\max \end{array}$ & $\begin{array}{c}\mathrm{Ti} \\
\max .\end{array}$ & $\begin{array}{c}B \\
\max \end{array}$ & $\begin{array}{l}\text { Mo } \\
\max .\end{array}$ & $\begin{array}{l}\mathrm{C}_{\mathrm{e}}^{* *} \\
\text { max. }\end{array}$ \\
\hline 0,12 & 0,60 & 2,10 & 0,008 & 0,015 & 0,015 & 0,09 & 0,20 & 0,22 & 0,005 & 0,50 & 0,61 \\
\hline \multicolumn{12}{|c|}{ Właściwości mechaniczne } \\
\hline \multicolumn{3}{|c|}{$\begin{array}{c}\text { Wytrzymałość na rozciąganie } \\
\mathrm{R}_{\mathrm{m}}, \mathrm{MPa}\end{array}$} & \multicolumn{3}{|c|}{$\begin{array}{c}\text { Granica plastyczności } R_{e} \\
M P a\end{array}$} & \multicolumn{3}{|c|}{$\begin{array}{l}\text { Wydłużenie } \mathrm{A}_{5}, \\
\%\end{array}$} & \multicolumn{3}{|c|}{$\begin{array}{l}\text { Udarność, } \mathrm{J} / \mathrm{cm}^{2} \\
\left(-20^{\circ} \mathrm{C}\right)\end{array}$} \\
\hline \multicolumn{3}{|c|}{822} & \multicolumn{3}{|c|}{768} & \multicolumn{3}{|c|}{19} & \multicolumn{3}{|c|}{135} \\
\hline
\end{tabular}

Suma zawartości $\mathrm{Nb}, \mathrm{V}$ i Ti powinna wynosić max. 0,22\%.

${ }^{* *} \mathrm{C}_{\mathrm{e}}$ - równoważnik węgla. 
Tablica II. Rzeczywisty skład chemiczny badanej stali S700MC o grubości 10 mm

Table II. The real chemical composition of the original S700 MC steel material

\begin{tabular}{|c|c|c|c|c|c|c|c|c|c|c|}
\hline \multicolumn{10}{|c|}{ Stężenie pierwiastków, \% wag. } \\
\hline $\mathrm{C}$ & $\mathrm{Mn}$ & $\mathrm{Si}$ & $\mathrm{S}$ & $\mathrm{P}$ & $\mathrm{Al}$ & $\mathrm{Nb}$ & $\mathrm{Ti}$ & $\mathrm{V}$ & $\mathrm{N}^{*}$ & $\mathrm{C}_{\mathrm{e}}$ \\
\hline 0,056 & 1,68 & 0,16 & 0,005 & 0,01 & 0,027 & 0,044 & 0,12 & 0,006 & 72 & 0,33 \\
\hline
\end{tabular}

${ }^{*} \mathrm{~N}$ :- : zawartość podana w ppm, azot wyznaczony metodą ekstrakcji wysokotemperaturowej.

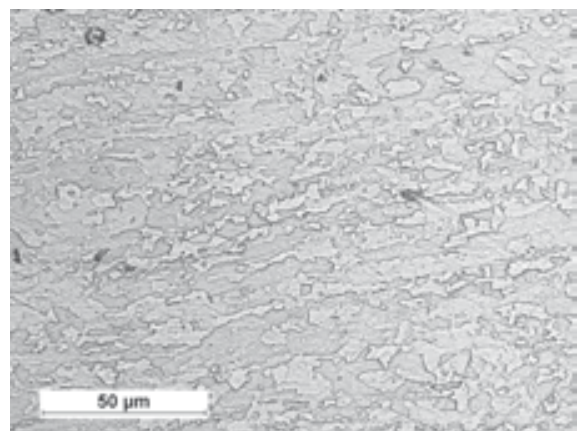

Rys. 1. Struktura bainityczno-ferrytyczna stali S700MC z widocznymi efektami odkształcenia plastycznego

Fig. 1. Structure of bainitic-ferritic steel S700MC with visible effects of plastic deformation

\section{Symulacja cykli cieplnych spawania}

W celu określenia wpływu maksymalnej temperatury cyklu na właściwości poszczególnych obszarów SWC badanej stali przeprowadzono symulację cykli cieplnych na specjalnie zbudowanym stanowisku badawczym wyposażonym w rezystancyjne źródło nagrzewania, kamerę termowizyjną Variocam Head HR oraz stanowisko komputerowe (rys. 2).

Układ rejestracji pól rozkładu temperatury składał się z kamery termowizyjnej Variocam Head HR firmy Infratec oraz komputera $z$ zainstalowanym oprogramowaniem Irbis 3 plus, umożliwiającym na sterowanie parametrami kamery oraz rejestrację obrazów termograficznych na dysku twardym komputera. Zastosowana kamera termowizyjna ma niechłodzoną matryce detektorów bolometrycznych, umożliwiającą pozyskiwanie obrazów termograficznych o rozdzielczości $640 \times 480$ pikseli i pomiar temperatury w zakresie od -40 do $2000^{\circ} \mathrm{C}$. Kamerę wyposażono $\mathrm{w}$ obiektyw o ogniskowej $\mathrm{f}=50 \mathrm{~mm}$, co przy odległości obiektywu od badanej próbki wynoszącej
$460 \mathrm{~mm}$ pozwoliło uzyskać pole widzenia $140 \times 110 \mathrm{~mm}$ oraz rozdzielczość przestrzenną obrazu termograficznego (IFOV) na poziomie $0,25 \mathrm{~mm}$. Do pomiaru temperatury kamerę skonfigurowano $w$ taki sposób, aby uzyskać jak najmniejszą niepewność pomiaru. Poza parametrami środowiskowymi, takimi jak temperatura otoczenia oraz wilgotność, przyjęto transmisyjność atmosfery równą $1 \mathrm{i}$ ustalono średnią emisyjność dla stali wynoszącą 0,9. Emisyjność jest kluczowym parametrem decydującym o dokładności pomiaru temperatury z zastosowaniem kamery termograficznej. Jest ona zależna od temperatury i stanu powierzchni obserwowanego obiektu. Przed badaniami przeprowadzono testy mające określić emisyjność próbek, która wahała się w granicach $0,5 \div 0,9$ dla obserwowanej powierzchni w zakresie temperatury $100 \div 900^{\circ} \mathrm{C}$. Podczas symulacji cyklu cieplnego zmieniały się właściwości powierzchni próbki w wyniku powstawania warstwy tlenków, co dodatkowo wpływało na podwyższenie wartości emisyjności. Wyniki wstępnych symulacji cyklu cieplnego próbek testowych potwierdziły, że przyjęta wartość emisyjności pozwala uzyskiwać wiarygodne wyniki obarczone średnim względnym błędem pomiaru temperatury nieprzekraczającym $10 \%$. Tor wizyjny przebiegał na wysokości $1550 \mathrm{~mm}$. Symulację wykonano w temperaturze powietrza $23,7^{\circ} \mathrm{C}$ oraz wilgotności powietrza $65,7 \%$. Badania symulacji cykli cieplnych polegały na nagrzewaniu rezystancyjnym próbek przygotowanych do badania udarności oraz rejestracji cyklu cieplnego nagrzewania i chłodzenia. Symulowano pojedyncze cykle cieplne w zakresie temperatury $400 \div 1300^{\circ} \mathrm{C}$, co $100^{\circ} \mathrm{C}$, oraz cykle złożone. W czasie badania rejestrowano przebieg temperatury w funkcji czasu oraz wyznaczono charakterystyczne parametry cyklu (tabl. III).
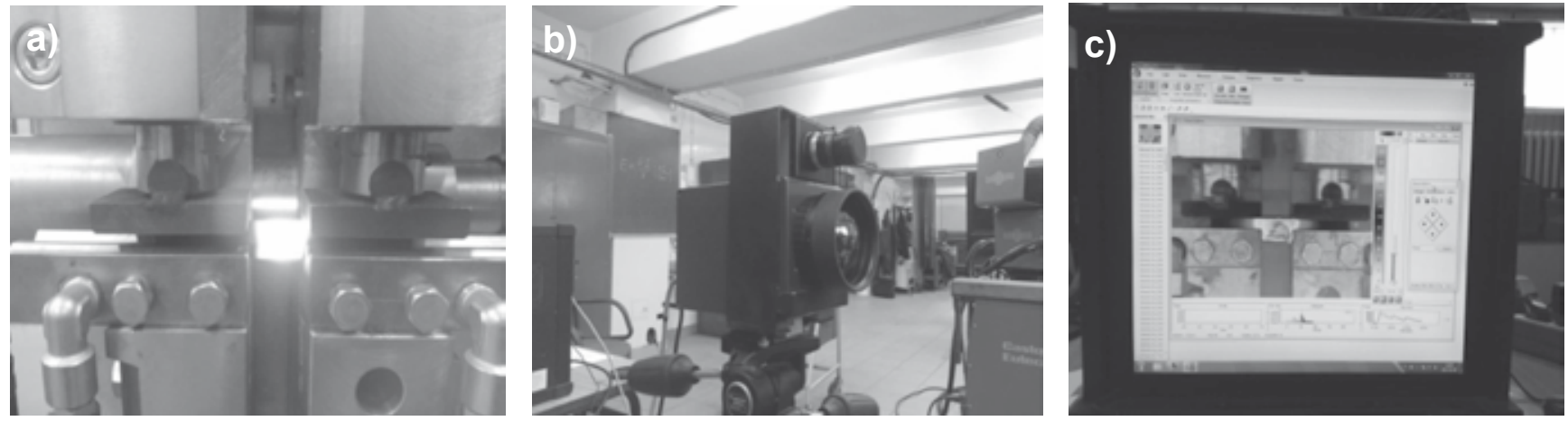

Rys. 2. Stanowisko badawcze do symulacji i rejestracji cykli cieplnych spawania: a) zgrzewarka rezystancyjna, b) kamera termowizyjna, c) stanowisko komputerowe

Fig. 2. Test and simulation of welding thermal cycles registration: a) resistance welding station, b) an infrared camera, c) computer 
Tablica III. Parametry symulowanych cykli cieplnych stali S700MC

Table III. The parameters of simulated thermal cycles steel S700MC

\begin{tabular}{|c|c|c|c|c|c|c|}
\hline \multirow{2}{*}{ Lp. } & \multicolumn{2}{|c|}{ Temperatura $\mathrm{T}_{\max },{ }^{\circ} \mathrm{C}$} & \multirow{2}{*}{$\underset{\mathrm{s}}{\text { Czas } \mathrm{t}_{\mathrm{n}}}$} & \multirow{2}{*}{$\begin{array}{c}\text { Czas } t_{8} \\
s\end{array}$} & \multirow{2}{*}{$\begin{array}{c}\text { Czas } t_{5} \\
\mathrm{~s}\end{array}$} & \multirow{2}{*}{$\begin{array}{c}\text { Czas } t_{8 / 5} \\
s\end{array}$} \\
\hline & zadana & rzeczywista & & & & \\
\hline 1 & \multirow{3}{*}{400} & 382 & 2,9 & - & - & - \\
\hline 2 & & 453 & 3,2 & - & - & - \\
\hline 3 & & 440 & 3,2 & - & - & - \\
\hline 4 & \multirow{3}{*}{500} & 518 & 2,7 & - & - & - \\
\hline 5 & & 552 & 2,7 & - & - & - \\
\hline 6 & & 480 & 2,8 & - & - & - \\
\hline 7 & \multirow{3}{*}{600} & 619 & 2,6 & - & - & - \\
\hline 8 & & 595 & 2,1 & - & - & - \\
\hline 9 & & 596 & 2,2 & - & - & - \\
\hline 10 & \multirow{3}{*}{700} & 720 & 2,8 & - & - & - \\
\hline 11 & & 720 & 2,4 & - & - & - \\
\hline 12 & & 736 & 2,1 & - & - & - \\
\hline 13 & \multirow{3}{*}{800} & 807 & 2,7 & 3,3 & 16,4 & 13,1 \\
\hline 14 & & 793 & 2,7 & 2,7 & 14,7 & 12,0 \\
\hline 15 & & 812 & 834 & 3,1 & 4,0 & 17,3 \\
\hline 16 & \multirow{3}{*}{900} & 904 & 3,4 & 6,6 & 19,3 & 12,7 \\
\hline 17 & & 929 & 3,6 & 7,4 & 19,8 & 12,4 \\
\hline 18 & & 912 & 3,6 & 7,3 & 19,8 & 12,5 \\
\hline 19 & \multirow{3}{*}{1000} & 1017 & 4,3 & 12,7 & 23,9 & 11,2 \\
\hline 20 & & 1020 & 4,1 & 11,9 & 23,7 & 11,8 \\
\hline 21 & & 1037 & 4,3 & 11,6 & 24,8 & 13,2 \\
\hline 22 & \multirow{3}{*}{1100} & 1136 & 4,4 & 13,6 & 25,6 & 12,0 \\
\hline 23 & & 1086 & 4,2 & 12,8 & 23,6 & 10,8 \\
\hline 24 & & 1099 & 3,9 & 12,4 & 23,3 & 10,9 \\
\hline 25 & \multirow{3}{*}{1200} & 1203 & 5,7 & 15,9 & 29,2 & 13,3 \\
\hline 26 & & 1178 & 5,4 & 15,6 & 29,2 & 13,6 \\
\hline 27 & & 1191 & 5,3 & 15,6 & 30,0 & 13,6 \\
\hline 28 & \multirow{3}{*}{1300} & 1282 & 5,2 & 18,8 & 33,0 & 14,2 \\
\hline 29 & & 1285 & 5,9 & 20,1 & 34,9 & 14,8 \\
\hline 30 & & 1275 & 5,7 & 20,6 & 35,9 & 14,2 \\
\hline 31 & \multirow{3}{*}{$\begin{array}{c}1100(500) / \\
700(300) / \\
500\end{array}$} & 1068 & 4,2 & 11,8 & 58,6 & 46,8 \\
\hline 32 & & 1080 & 3,6 & 12,1 & 59,4 & 47,3 \\
\hline 33 & & 1140 & 3,9 & 13,1 & 60,3 & 47,2 \\
\hline 34 & \multirow{3}{*}{$\begin{array}{c}1200(500) / \\
900(400) / \\
700\end{array}$} & 1240 & 5,9 & 28,2 & 65,0 & 36,7 \\
\hline 35 & & 1190 & 5,4 & 26,8 & 64,3 & 37,5 \\
\hline 36 & & 1238 & 5,8 & 27,9 & 65,1 & 37,2 \\
\hline 37 & \multirow{3}{*}{$\begin{array}{c}1300(800) / \\
1100(500) / \\
900\end{array}$} & 1299 & 6,6 & 36,0 & 68,2 & 32,2 \\
\hline 38 & & 1278 & 5,6 & 20,7 & 75,5 & 54,8 \\
\hline 39 & & 1321 & 6,7 & 39,2 & 78,2 & 39,0 \\
\hline
\end{tabular}

\section{Badania próbek symulowanych}

Próbki uzyskane po procesie symulacji zostały poddane badaniom udarności zgodnie z PN-EN ISO 1481:2010, na próbkach $z$ karbem typu $V$, na młocie udarowym Zwick/Roell RKP $450 \mathrm{w}$ temperaturze $-30^{\circ} \mathrm{C}$, a także pomiarowi twardości metodą Vickersa przy obciążeniu 9,81 N (HV1) na urządzeniu Wilson Wolpert Micro-Vickers 401MVD zgodnie z wymaganiami PN-EN ISO 9015-1. Na każdej próbce wykonano po 7 pomiarów. Następnie dwie skrajne wartości (minimum i maksimum) odrzucono, a dla pozostałych pięciu pomiarów w serii obliczono wartości średnie. Badania 
metalograficzne mikroskopowe przeprowadzono na mikroskopie świetlnym Nikon Eclipse MA100, próbki do badań trawiono w nitalu. Badania wytrzymałości na rozciąganie wykonano na podstawie normy PN-EN 10002-1 na próbkach okrągłych. Badania przeprowadzono na maszynie wytrzymałościowej MTS Insight. Maszyna ta umożliwia wymuszanie przemieszczenia belki poprzecznej (trawersu), na której znajduje się czujnik siły, ze stałą prędkością. Czujnik siły, w który jest wyposażona maszyna MTS Insight, pozwala na pomiar siły do $10 \mathrm{kN} \mathrm{z}$ dokładnością do dziesiętnych części N. W celu spełnienia wymagań dotyczących statycznego testu rozciągania próbek przyjęto prędkość testu: $5 \mathrm{~mm} / \mathrm{min}$. Testy statycznego rozciągania prowadzono w temperaturze $24^{\circ} \mathrm{C}$ przy wilgotności powietrza wynoszącej $59 \%$. W celu uniknięcia deformacji próbek w momencie ich mocowania w uchwytach pneumatycznych maszyny wytrzymałościowej, a przy tym generowania siły wstępnej, tzw. pre-loadu, ustalono minimalne ciśnienie zacisku uchwytów, przy którym próbka została zamocowana w sposób pewny. Wartość tego ciśnienia wynosiła 0,27 MPa. Powtarzalność osiowości i głębokości uchwycenia kształtki była możliwa dzięki zastosowaniu uchwytów pryzmatycznych. Głębokość zamocowania próbki w uchwytach była równa długości jej części chwytowej.

\section{Analiza wyników badań}

Symulację cykli cieplnych prostych SWC stali S700MC prowadzono w zakresie temperatury maksymalnej $400 \div 1300^{\circ} \mathrm{C}$ oraz wybranych cykli cieplnych złożonych w zakresie temperatury maksymalnej $1100 \div 1300^{\circ} \mathrm{C}$ (rys. 3). Czas nagrzewania mieścił się w zakresie $2,3 \div 5,6 \mathrm{~s}$. Czas chłodzenia $t_{8 / 5}$ cykli cieplnych o maksymalnej temperaturze $\mathrm{T}_{\max }$ powyżej $800^{\circ} \mathrm{C}$ utrzymywano na poziomie $11 \div 15$ s. Taki zakres czasu chłodzenia wynikał z analizy badań przemian fazowych austenitu w czasie chłodzenia - wykres CTPc-S [9].

W tym zakresie czasu $t_{8 / 5}$ stal S700MC charakteryzuje się strukturą bainityczno-ferrytyczną o relatywnie małym ziarnie i twardości zbliżonej do twardości materiału rodzimego. Badania metalograficzne mikroskopowe symulowanych obszarów SWC wykazały, że w zakresie maksymalnych temperatur cyklu od 400 do $900^{\circ} \mathrm{C}$ stal S700MC charakteryzuje się drobnoziarnistą strukturą bainityczno-ferrytyczną. Powyżej maksymalnej temperatury cyklu $900^{\circ} \mathrm{C}$ następuje silny rozrost ziarna i postępuje on do temperatury $1300^{\circ} \mathrm{C}$ (tabl. IV). Wysoka temperatura maksymalnych cykli cieplnych nagrzewania niweluje wpływ faz umacniających na rozdrobnienie ziarna austenitu i powoduje utratę właściwości nabytych na drodze obróbki termomechanicznej. Szczególnie jest to widoczne w przypadku cykli cieplnych złożonych. Badania mikroskopowe ujawniły obecność dużych wydzieleń węglikoazotkowych w obszarach wszystkich symulowanych SWC (tabl. IV), co świadczy o ich wysokiej trwałości termicznej.
Badania twardości symulowanych obszarów SWC wykonane metodą Vickersa wykazały niewielki wpływ przemiany fazowej austenitu podczas chłodzenia na właściwości stali S700MC. Twardość obszarów SWC nagrzewanych w zakresie maksymalnych temperatur cyklu $400 \div 900^{\circ} \mathrm{C}$ nie ulega zmianie i jest zbliżona do twardości materiału rodzimego. Wraz ze wzrostem temperatury maksymalnego cyklu cieplnego powyżej $900^{\circ} \mathrm{C}$ następuje zmiękczenie materiału do poziomu ok. 230 HV1 (rys. 4). Również w przypadku cykli cieplnych złożonych wraz ze wzrostem maksymalnej temperatury cyklu twardość symulowanej SWC maleje.

Badania udarności symulowanych obszarów SWC wykonane $\mathrm{w}$ temperaturze $-30^{\circ} \mathrm{C}$ wykazały istotny wpływ maksymalnej temperatury cyklu cieplnego na właściwości plastyczne stali. Obszary SWC nagrzewane od 400 do $700^{\circ} \mathrm{C}$ charakteryzują się udarnością niższą niż udarność materiału rodzimego (rys. 5, 6). Spadek udarności w tym zakresie temperaturowym należy wiązać z procesami starzeniowymi, dyfuzją atomów węgla i azotu na bliskie odległości do jąder dyslokacji i ich zablokowaniem. W zakresie temperatury $800 \div 900^{\circ} \mathrm{C}$ następuje gwałtowny wzrost udarności do poziomu $300 \mathrm{~J} / \mathrm{cm}^{2}$, co należy wiązać z zanikiem umocnienia wydzieleniowego przez koagulację wydzieleń i przejściem składników umacniających do osnowy oraz procesami rekrystalizacji ziarna [9].

Badania wytrzymałości na rozciąganie próbek okrągłych pobranych z obszarów SWC stali poddanej cyklom cieplnym w zakresie maksymalnej temperatury $400 \div 700^{\circ} \mathrm{C}$ wykazały wytrzymałość na rozciąganie zbliżoną do wytrzymałości materiału rodzimego. Wraz ze wzrostem maksymalnej temperatury cyklu nagrzewania następuje wyraźny spadek wytrzymałości na rozciąganie SWC w stosunku do materiału rodzimego - pow. $100 \mathrm{MPa}$ (rys. 7). Również w cyklach cieplnych złożonych wraz ze wzrostem temperatury nagrzewania SWC maleje, wytrzymałość na rozciąganie. Osiągane wartości wydłużenia SWC nagrzewanej w zakresie temperatury $400 \div 700^{\circ} \mathrm{C}$ są na poziomie $12 \%$, przy wydłużeniu materiału rodzimego ok. 16\%. Wraz ze wzrostem temperatury nagrzewania SWC wydłużenie maleje osiągając wartości ok. 6\% (rys. 8). W przypadku cykli cieplnych złożonych wzrost temperatury nagrzewania SWC również powoduje pogorszenie właściwości plastycznych stali.

Z przeprowadzonych badań wynika, że rzeczywista SWC na swoim przekroju charakteryzuje się zmiennymi właściwościami. Najbardziej niebezpiecznym obszarem SWC o niskich właściwościach plastycznych jest jej część wysokotemperaturowa, gruboziarnista, nagrzana powyżej $1200^{\circ} \mathrm{C}$. Obszary SWC nagrzane do temperatury $800 \div 900^{\circ} \mathrm{C}$ charakteryzują się najwyższą udarnością. Widoczny jest wtedy zanik efektu umocnienia wydzieleniowego, ograniczenie rozrostu ziarna i w konsekwencji zmniejszenie odcinka przegrzania SWC. W związku z tym proces spawania należy prowadzić w taki sposób, aby zminimalizować szerokość niekorzystnych obszarów SWC. 

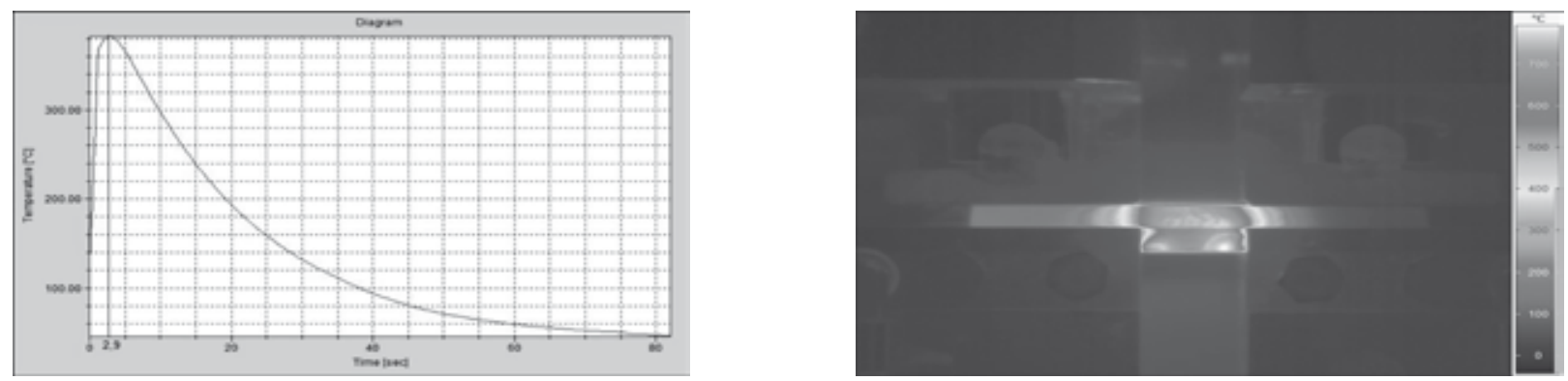

Temperatura cyklu $T_{\max }=400^{\circ} \mathrm{C}$
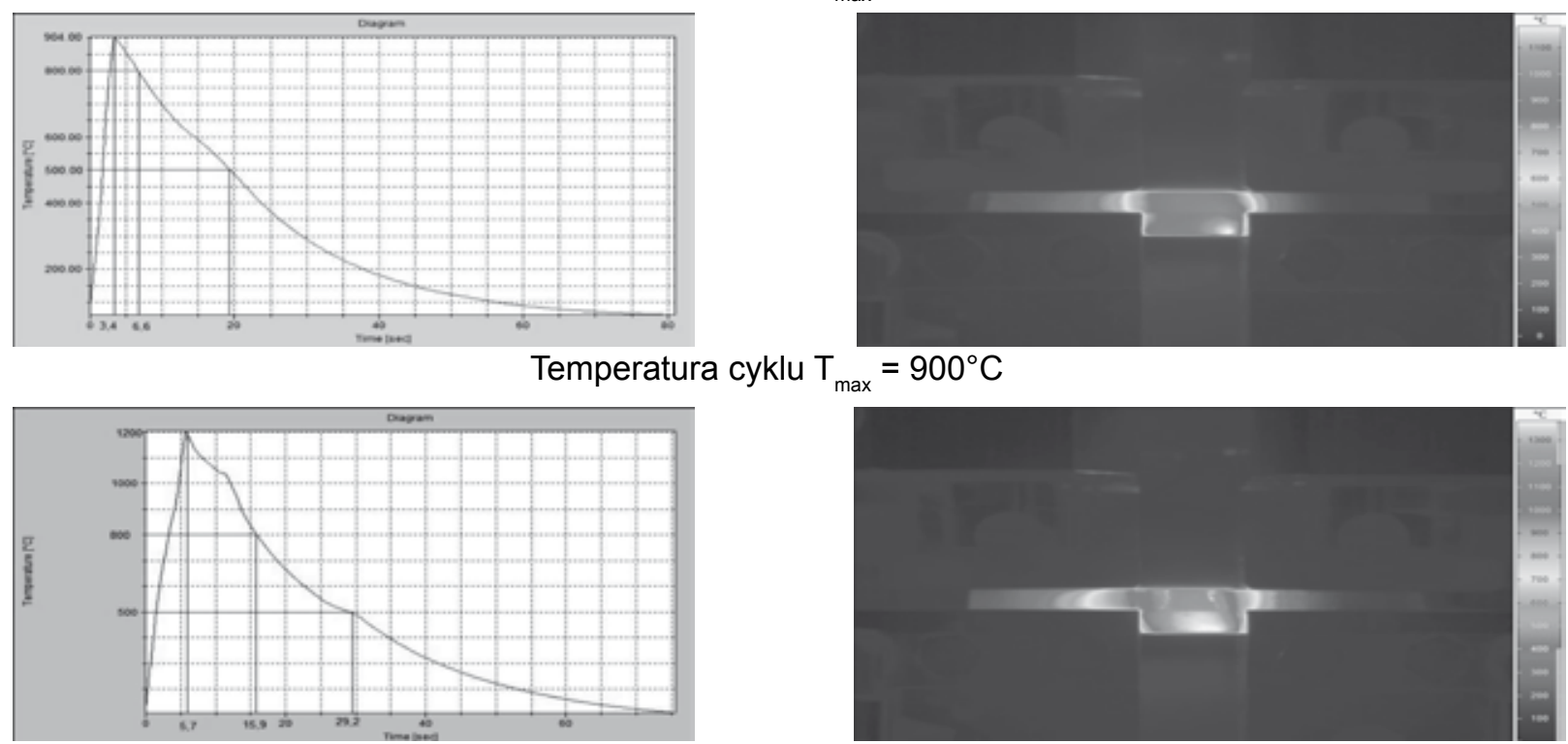

Temperatura cyklu $\mathrm{T}_{\max }=1200^{\circ} \mathrm{C}$
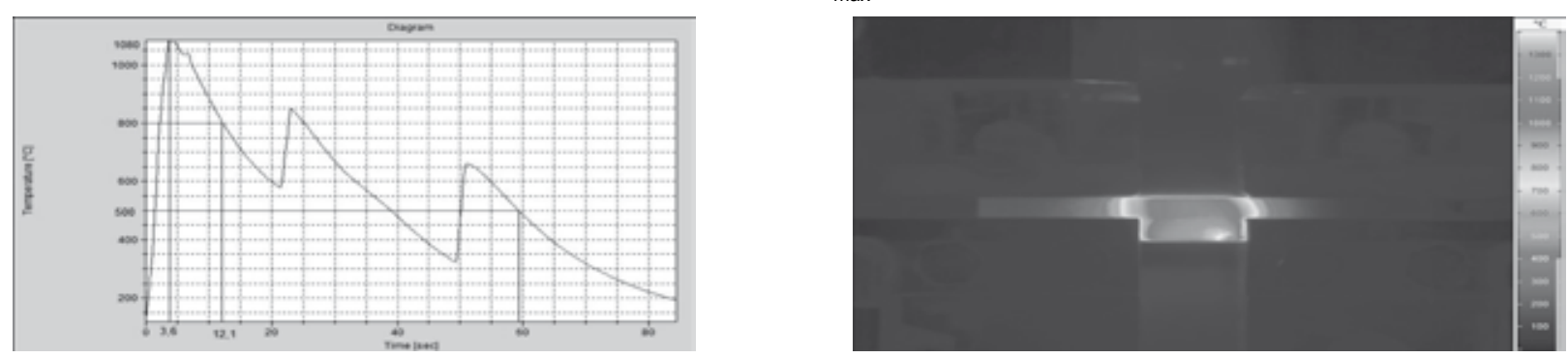

Temperatura cyklu złożonego $\mathrm{T}_{\max }=1100^{\circ} \mathrm{C}$

Rys. 3. Przebiegi wybranych cykli cieplnych symulowanej SWC stali S700MC wraz z termogramami Fig. 3. Waveforms of selected simulated HAZ thermal cycles in S700MC steel with thermal image

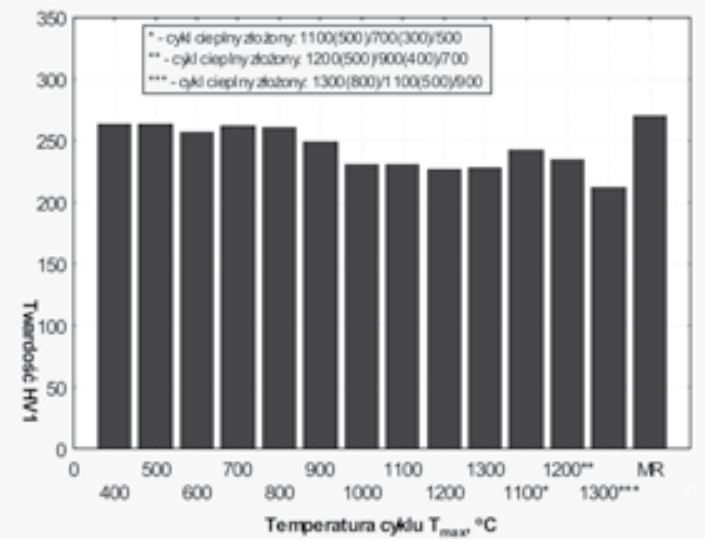

Rys. 4. Wyniki pomiarów twardości HV1 symulowanych obszarów SWC stali S700MC

Fig. 4. Results of measurements of hardness HV1 simulated HAZ areas of S700MC steel



Rys. 5. Udarność symulowanej SWC stali S700MC w temp.- $30^{\circ} \mathrm{C}$ Fig. 5. Impact strength steel $\mathrm{S} 700 \mathrm{MC}$ simulated $\mathrm{HAZ}$ at $-30^{\circ} \mathrm{C}$ 
Tablica IV. Mikrostruktura obszarów SWC stali S700MC w funkcji temperatury $\mathrm{T}_{\max }$

Table IV. Microstructure HAZ areas S700MC steel as a function of temperature $\mathrm{T}_{\max }$

\begin{tabular}{|c|c|c|}
\hline 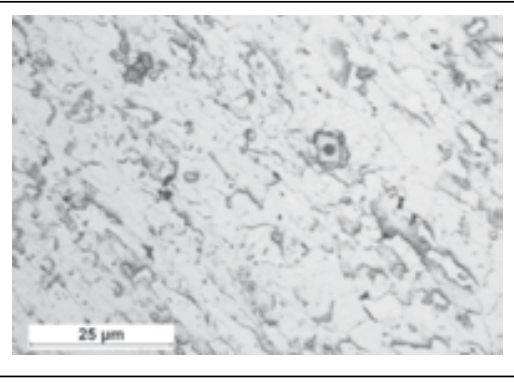 & 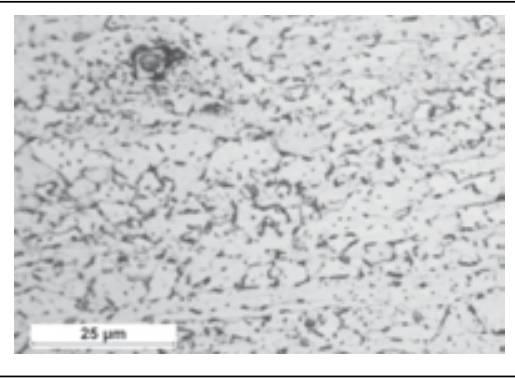 &  \\
\hline $\mathrm{T}_{\max }=400^{\circ} \mathrm{C} ; 264 \mathrm{HV} 1$ & $\mathrm{~T}_{\max }=500^{\circ} \mathrm{C} ; 263 \mathrm{HV} 1$ & $\mathrm{~T}_{\max }=600^{\circ} \mathrm{C} ; 257 \mathrm{HV} 1$ \\
\hline  & 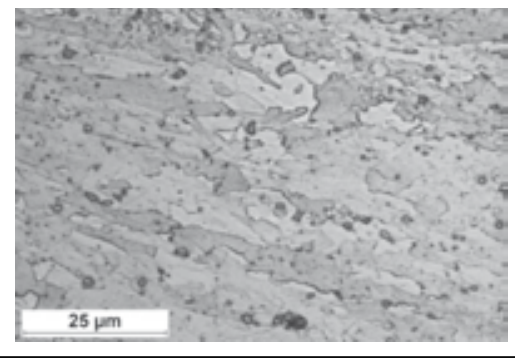 & 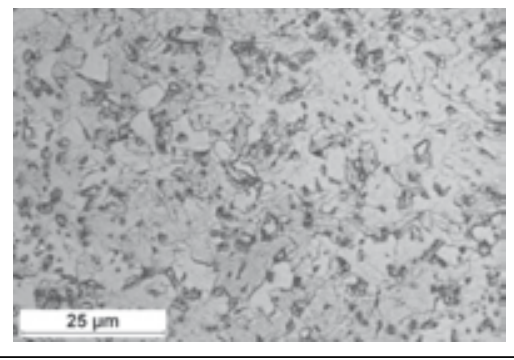 \\
\hline $\mathrm{T}_{\max }=700^{\circ} \mathrm{C} ; 262 \mathrm{HV} 1$ & $\mathrm{~T}_{\max }=800^{\circ} \mathrm{C} ; 261 \mathrm{HV} 1$ & $\mathrm{~T}_{\max }=900^{\circ} \mathrm{C} ; 249 \mathrm{HV} 1$ \\
\hline 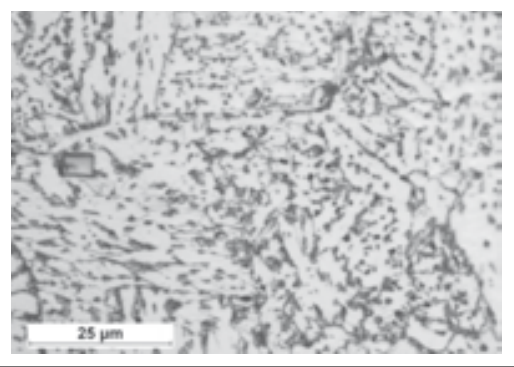 & ation & 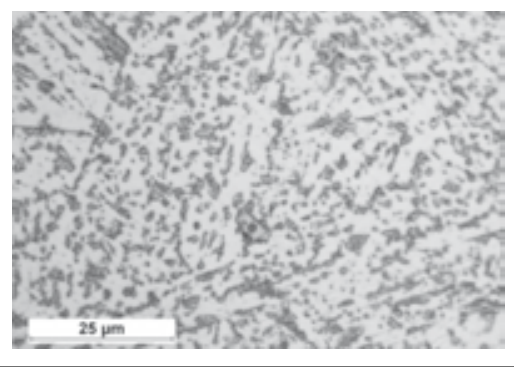 \\
\hline $\mathrm{T}_{\max }=1000^{\circ} \mathrm{C} ; 231 \mathrm{HV} 1$ & $\mathrm{~T}_{\max }=1100^{\circ} \mathrm{C} ; 230 \mathrm{HV} 1$ & $\mathrm{~T}_{\max }=1200^{\circ} \mathrm{C} ; 226 \mathrm{HV} 1$ \\
\hline 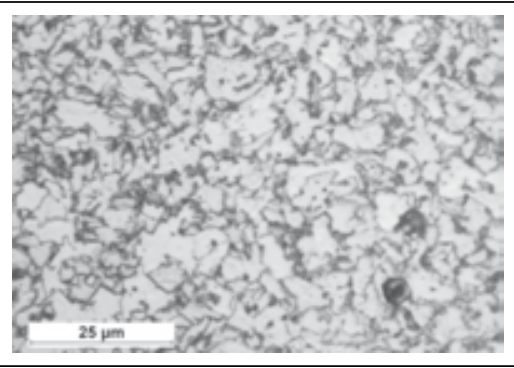 & as & 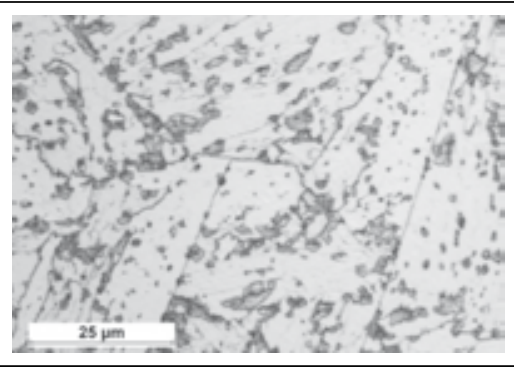 \\
\hline $\begin{array}{c}\mathrm{T}_{\max }=1100^{\circ} \mathrm{C} ; \text { cykl złożony } \\
243 \mathrm{HV} 1\end{array}$ & $\begin{array}{c}\mathrm{T}_{\max }=1200^{\circ} \mathrm{C} ; \text { cykl złożony } \\
234 \mathrm{HV} 1\end{array}$ & $\begin{array}{c}\mathrm{T}_{\max }=1300^{\circ} \mathrm{C} \text {; cykl złożony } \\
212 \mathrm{HV} 1\end{array}$ \\
\hline
\end{tabular}

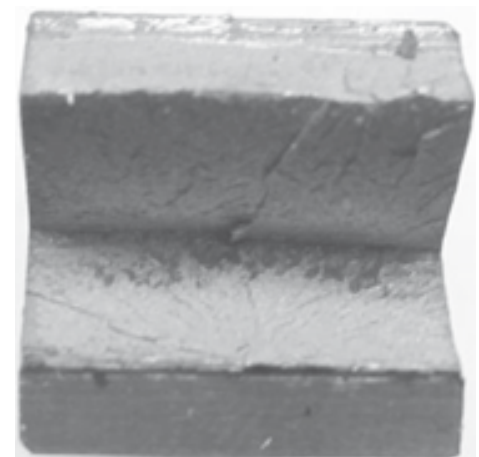

Przełom mieszany $\mathrm{T}_{\max }=500^{\circ} \mathrm{C}$

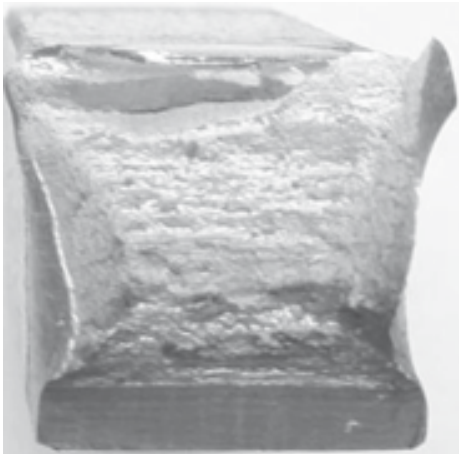

Przełom plastyczny $\mathrm{T}_{\max }=900^{\circ} \mathrm{C}$

Rys. 6. Przełomy SWC stali S700MC po próbie udarności w temperaturze $-30^{\circ} \mathrm{C}$

Fig. 6. View of S700MC steel HAZ fracture after an impact test at $-30^{\circ} \mathrm{C}$



Przełom kruchy $\mathrm{T}_{\max }=1200^{\circ} \mathrm{C}$ 


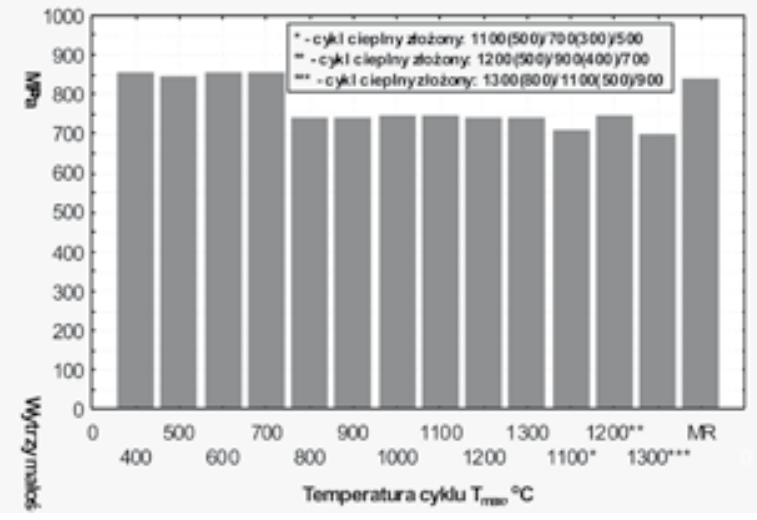

Rys. 7. Wytrzymałość na rozciąganie symulowanej SWC stali S700MC Fig. 7. Tensile strength of steel S700MC simulated HAZ



Rys. 8. Wydłużenie symulowanej SWC stali S700MC

Fig. 8. Relative elongation of the simulated HAZ steel S700MC

\section{Podsumowanie}

Stal S700MC charakteryzuje się silnie zdefektowaną strukturą bainityczno-ferrytyczną. Bardzo niska zawartość węgla $(0,05 \%)$, który w dużej części został związany przez $\mathrm{Ti}$ oraz $\mathrm{Nb}$, skutkuje zmniejszeniem jego udziału w umocnieniu stali i ogranicza jego oddziaływanie w przemianach fazowych i strukturalnych. W obszarze wtopienia i SWC zaobserwowano obecność wydzieleń o wielkości od kilkunastu do kilkudziesięciu $\mu \mathrm{m}$, które nie biorą udziału w umocnieniu stali iograniczeniu rozrostu ziarna, tylko stanowią karb oraz obniżają właściwości wytrzymałościowe i plastyczne złączy spawanych. Istotny wpływ na właściwości złączy spawanych stali obrabianych termomechanicznie wywiera obszar SWC, zwłaszcza ten nagrzany do bardzo wysokiej temperatury $\left(1250 \div 1400^{\circ} \mathrm{C}\right)$. Badania symulowanych obszarów SWC, nagrzewanych do różnych maksymalnych temperatur, wykazały znaczne ich zróżnicowanie pod względem właściwości wytrzymałościowych i plastycznych. Właściwości wytrzymałościowe po przekroczeniu temperatury cyklu cieplnego o maksymalnej temperaturze $600^{\circ} \mathrm{C}$ maleją w stosunku do materiału rodzimego, co związane jest przede wszystkim z rozrostem ziarna. Właściwości plastyczne symulowanych SWC (zwłaszcza udarność) zależą od trwałości faz umacniających, ich dyspersji oraz od procesów starzeniowych. Obszary SWC nagrzewane od 400 do $700^{\circ} \mathrm{C}$ charakteryzują się udarnością niższą niż udarność materiału rodzimego, co należy wiązać prawdopodobnie z procesami starzeniowymi, dyfuzją atomów węgla i azotu na bliskie odległości do jąder dyslokacji i ich unieruchomieniem. Symulowane obszary SWC nagrzane do temperatury $800^{\circ} \mathrm{C}$ i $900^{\circ} \mathrm{C}$ wykazuja bardzo wysoką udarność, sięgającą $300 \mathrm{~J} / \mathrm{cm}^{2}$. Tak duży wzrost udarności związany jest z przejściem składników umacniających do osnowy i w konsekwencji zanikiem umocnienia wydzieleniowego oraz procesami rekrystalizacji. W wysokotemperaturowym obszarze SWC gwałtowny spadek udarności do kilku $\mathrm{J} / \mathrm{cm}^{2}$ związany jest ze wzrostem rozpuszczonych mikrododatków umacniających $w$ osnowie $\mathrm{i}$ ich niekontrolowanym wydzielaniem w czasie chłodzenia. Uzyskane wyniki badań wykazały, że przemiana fazowa austenitu podczas chłodzenia nie odgrywa dominującej roli w zapewnieniu odpowiednich właściwości wytrzymałościowych i plastycznych złączy spawanych stali obrabianej termomechanicznie S700MC.

\section{Literatura}

[1] Węgrzyn J.: Fizyka i metalurgia spawania, Politechnika Śląska, Gliwice 1990.

[2] Brózda J., Pilarczyk J., Zeman M.: Spawalnicze wykresy przemian austenitu CTPc-S, Wydawnictwo Śląsk, Katowice 1983.

[3] Poradnik inżyniera, Spawalnictwo, t. 1 (pod red. J. Pilarczyka) WNT, Warszawa 2003.

[4] Górka J.: Wpływ temperatury podgrzewania wstępnego na właściwości i strukturę złączy spawanych stali obrabianej termomechanicznie S700MC, XIX Naukowo-Techniczna Krajowa Konferencja Spawalnicza, Postęp, innowacje i wymagania jakościowe procesów spawania, Międzyzdroje 04-06.06. 2013, s. 59-70.

[5] Brózda J.: Nowoczesne stale konstrukcyjne i ich spawalność. Wydawnictwo Instytutu Spawalnictwa, Gliwice 2009.

[6] Tasak E., Ziewiec A.: Spawalność materiałów konstrukcyjnych, t. 1, Spawalność stali, Kraków 2009.

[7] Yurioka M.: TMCP steel and their welding, Welding in the World, vol. 35, 6/1995, s. 375-390.

[8] Meester B.: The weldability of modern structural TMCP steel. ISIJ International, vol. 37, 1997, No. 6, s. 537-551.

[9] Górka J.: Właściwości i struktura złączy spawanych stali obrabianej termomechanicznie o wysokiej granicy plastyczności, Monografia habilitacyjna, Gliwice 2013. 